\title{
PROFESSORES, ALUNOS E OS MEANDROS DE SUAS RELAÇÕES: UMA PONDERAÇÃO SOBRE DA AUTORIDADE PEDAGÓGICA À AMIZADE INTELECTUAL, DE JULIO GROPPA AQUINO.
}

\author{
Resenha do livro: \\ AQUINO, J. G. Da autoridade pedagógica à amizade intelectual: uma plataforma \\ para o éthos docente. São Paulo: Cortez Editora, 2014.
}

\author{
Por: Carlos Herold Junior ${ }^{1}$
}

Júlio Groppa Aquino é professor da Faculdade de Educação da USP. Os resultados de suas pesquisas são possíveis de serem acessados através de um amplo leque de artigos e livros publicados nos últimos anos. Em 2014, ele lançou Da autoridade pedagógica à amizade intelectual: uma plataforma para o éthos docente, pela Cortez Editora. A obra foi nominada e classificada em terceiro lugar no Prêmio Jabuti, de 2015, na área de Educação e Pedagogia.

As reflexões de Aquino estão organizadas em cinco capítulos. Antes deles, lemos uma interessante introdução na qual o pesquisador explica as razões que o levaram a produzir a obra em tela, bem como os limites e as ambições que o impulsionam. Trata-se de "oferecer uma mirada caleidoscópica sobre o espírito da época acerca do pensar e do agir docentes" (p.22) por meio do que ele chama de um "livro-testemunho" (p.21), podendo ser entendido por isso um documento no qual o autor se manifesta na tentativa de escrutinar suas experiências como um professor formador de professores. São mais de 25 anos de trabalho que estimulam uma "acareação entre a esfera das ideias pedagógicas e a empiria escolar" (p.24), uma vontade de "reinvenção entusiasmada do que ali se passa" (p.23), manifesto em um "acalorado e íntimo pedido de amizade intelectual" (p.27).

O capítulo I intitula-se Um padre, um romancista e três filósofos: os contornos da autoridade. Para estipular a "validação das posições de cada um dos jogadores" (p.63) professores e alunos - no que Aquino chama de "jogo pedagógico" (p.63), são aproximados para um diálogo intelectuais distantes entre si, espacial e temporalmente: Padre Antônio Vieira, Carlos Heitor Cony, Paul Ricoeur e Bertrand Russel. O eixo da reflexão é o relacionamento professor-aluno, abordando-o pelos recorrentes dilemas entre autoridade e liberdade, diretividade e não-diretividade, enfim, o "jargão psicopedagógico contemporâneo" (p.80). Para o autor, uma educação democrática estaria menos conectada ao culto às idiossincrasias infantis (em uma ótica que não desconsidera sua relevância para um bom número de problemáticas formativas), em favor do apego a uma "prática exigente e generosa da autoridade" (p.80), visando a uma "lapidação intelectual dos alunos para a admissão no mundo dos feitos humanos e sua complexidade característica" (p.80).

A autoridade interrogada: a réplica das novas gerações é o título do segundo capítulo. Aquino busca colocar em evidência as constantes lamentações da "doxa pedagógica" (p.105) sobre a indisciplina do alunado. Esse discurso é investigado através de um "recenseamento" (p.101) que busca pensar a criticável aproximação entre as análises que conectam a indisciplina escolar e a violência, dando conta de uma "crença social generalizada" (p.92) a respeito do "desencaixe" (p.87) entre a escola e as crianças e jovens que a frequentam. O autor enxerga nesse posicionamento, "prenhe de contestação" (p.101), uma "demanda acirrada de disciplinamento das vidas escolares" (p.101). Interessante verificar que em um momento de grande questionamento sobre as estruturas escolares, fecha-se o cerco ao "conflito, divergência, disparidade, dissenso" (p.99), eliminando, desse 
modo, possibilidades concretas (porém sabidamente difíceis de gerir em qualquer estrutura institucional, ainda mais a escolar) para superarmos a "esgarçadura do modus operandi escolar clássico" (p.110).

$\mathrm{Na}$ continuidade da reflexão, o conceito de governamentalidade é tomado como suporte analítico. Intitulado $O$ presente educacional e as transformações do éthos docente, o capítulo III debruça-se sobre as "modulações normativas incrustadas nas ações corriqueiras" (p.124). O referencial foucaultiano adotado pelo autor vai produzindo seus efeitos ao deixar em evidência que essa normatização tem nos espaços escolares seu "lócus fundador" (p.126), com processos, ao mesmo tempo, individualizadores e totalizadores. Uma resultante característica do mundo educacional contemporâneo é o fato desse processo de governamentalização gerar um "approach pedagogizante" (p.130), manuseado por experts das relações humanas, tipicamente escolares, cujos conselhos espraiam-se para além da escola, pedagogizando muitos aspectos da vida cotidiana, o que é assumido como mais um dos "modos de exercer o poder" (p.132). Longe de enxergar que isso tem deixado a movimentação dos atores da cena escolar mais fácil, Aquino evidencia que em meio a essa ampliação de discursos normatizadores, a escola se tornou uma "instituição à deriva" (p.145), impactada pela agudização de muitas angústias lá vividas por alunos e professores. A demonstração dessa percepção é feita por meio da análise da obra Entre os muros da escola, escrito em 2006 por François Bégaudeau (2009) e adaptado para o cinema em 2008. Depois de abordar a problemática pela ótica cinematográfica - ótica essa muito marcada pela oscilação entre caracterizações que ora veem o professor como vítima, ora como algoz, ora como taumaturgo -, Aquino nota que, contrariamente aos frequentes anúncios sobre o fim, a crise e o já mencionado desencaixe educacional no contemporâneo, é possível notar, mesmo que turvamente, o seu contrário. Essa ideia proporciona um contrapé muito interessante ao leitor, se considerarmos a constatação acima analisada, deixando clara a complexidade da situação:

Nesse sentido, a irradiação de práticas pedagógicas de natureza não formal estaria deslindando não uma suposta decadência do projeto escolar moderno, mas um deslocamento do epicentro nervoso da tradição educativa, antes ocupado exclusivamente pela instituição escolar. Ou seja, o presente educacional ter-se-ia convertido em algo demasiado voraz para se satisfazer apenas com sua versão formal (AQUINO, 2014, p.152).

Perante o diagnóstico dos mecanismos de governamentalização em funcionamento na educação e na instituição escolar, as possibilidades de lidar com os discursos produzidos e repetidos por esse processo são tratadas no capítulo IV. Na expectativa de gerar "um gesto radicalmente crítico sobre nós próprios" (p.154), construída a partir da reflexão feita no capítulo III, Aquino vê na consideração filosófica da Amizade um caminho para viabilizar "a experiência ético-estética" (p.154) que pode ainda existir no contexto educacional e nas relações entre professores e alunos. Tendo como título A amizade intelectual: aproximações, temos nesse momento do livro a indicação de vias reflexivas que contornem "enquadres interpretativos saturados" (p.157). Embora seja este o capítulo mais breve, é nele que Aquino perspectiva a plataforma do éthos docente, que nomina o livro. Essa possibilidade é vislumbrada na difícil conjunção de uma vivência do mundo contemporâneo que, ao mesmo tempo, guarde "distância das estridências" (p.159), mas que assuma a "indeterminação em vez de assistir a atrofia da vontade de experimentar" (p.160). Para tanto, uma ética pautada na amizade, no reconhecimento pronto do outro pode se tornar um "princípio da ação docente" (p.179). Pedagogicamente considerada, a 
amizade surge como condição incontornável para uma "expansão existencial recíproca" (p.180), onde professores e alunos encontram-se "desarmadamente", mesmo que nesse encontro as rusgas sempre estejam presentes. Na execução das possibilidades culturais que dão existência à escola, a realização do assim chamado éthos docente pode se tornar uma postura fundamental para a efetiva concretização de uma das principais ambições do mandato escolar desde sua fundação: "Em suma, cumprir-nos-ia deixar para os que virão aquilo que, não obstante inteiramente reconstituído por nós, já nos havia sido deixado pelos que se foram"(p.185).

Dois pontos podem ser destacados para evidenciar a importância do livro de Aquino. O primeiro é a abordagem de característica literária, filosófica e histórica das relações humanas que se travam no contexto escolar. Esse traço vai de encontro ao consagrado viés pedagogizante e psicologizante com que essas relações são abordadas. Embora ainda haja considerações importantes a serem aprendidas com essa tradição, é notória a dificuldade que ela possui para fazer frente às transformações que assistimos no mundo contemporâneo. Nele, as antigas prescrições, como o próprio livro demonstra, parecem ganhar volume na mesma medida em que são cada vez ignoradas por todos aqueles a quem se destinam, em que pese essa ineficácia não deixar de implicar sua potência governamentalizadora, para ficarmos com o diagnóstico de Aquino.

Por fim, outro distintivo muito marcante ao lado do desenvolvimento e conclusões do trabalho encontra-se na apresentação à obra. Aqui, Júlio Groppa Aquino posiciona sua reflexão e a sua própria trajetória de um modo a deixar claros seus pontos de partida profissionais e a forma como os aborda filosoficamente, explicando com maestria como esse conjunto impacta sua escrita e sua ação em sala de aula. O resultado é uma reflexão que se anuncia dialogada e se consuma desse modo, em um procedimento em que as vivências do autor estão sempre presentes e justificam cada apoio que ele busca na tradição filosófica que adota. Esse grande trunfo metodológico e a riqueza gerada em seu manuseio colocam Da autoridade pedagógica à amizade intelectual como uma obra de grande valor para abordamos questões de grande urgência sobre a educação e a escola no mundo atual.

Referência

AQUINO, J. G. Da autoridade pedagógica à amizade intelectual: uma plataforma para o éthos docente. São Paulo: Cortez Editora, 2014.

BÉGAUDEAU, F. Entre os muros da escola. São Paulo: Martins Fontes, 2009.

\footnotetext{
${ }^{1}$ Professor Associado, Departamento de Educação Física, Universidade Estadual de Maringá - UEM
} 